\title{
Stability of Structure, Phase and Elemental Composition of Chemically Deposited and Electrodeposited Gold Layers in Multilayer Systems $\mathrm{A} \mathbf{u}_{\text {chemically reduced; electrodeposited }} / \mathrm{Co}-\mathrm{W} / \mathrm{Cu} \mathbf{u}_{\text {sputtered }} /$ Glass-Ceramics
}

\author{
Ingrīda Vītiņa*, Velta Belmane, Aija Krūmiṇa, Māra Lubāne
}

Institute of Inorganic Chemistry, Riga Technical University, 34 Miera Str., Salaspils-1, LV-2169, Latvia

\begin{abstract}
The changes in the structure and elemental composition of $\mathrm{Au}$ and $\mathrm{Co}-\mathrm{W}$ thin layers after thermal treatment of $200 \mathrm{~h}$ at $200-300{ }^{\circ} \mathrm{C}$ and $50 \mathrm{~h}$ at $450{ }^{\circ} \mathrm{C}$ were systematically studied using the X-ray microanalysis of scanning electron microscope XL-30 ESEN Philips. The phase stability was evaluated by X-ray diffraction (XRD). The electrodeposited Co-W layer (W 46.0-53.0 wt. \% depending on the electrodeposition regime) is amorphous and maintains its amorphous state after heating at $200{ }^{\circ} \mathrm{C}$ for $200 \mathrm{~h}$ and subsequent heating $(+)$ at $300{ }^{\circ} \mathrm{C}$ for $150 \mathrm{~h} . \mathrm{Co}-\mathrm{W}$ amorphous layers prevent interdiffusion of $\mathrm{Au}$ and $\mathrm{Cu}$ atoms and formation of intermetallics $\mathrm{AuCu}$ in the systems of layers $\mathrm{Au}$ chemically reduced; $\mathrm{Au}$ electrodeposited $/ \mathrm{Co}-\mathrm{W} / \mathrm{Cu}_{\text {sputtered }} /$ glass-ceramics. The chemically reduced $0.4 \mu \mathrm{m} \mathrm{Au}$ layers maintain their structure and phase in the systems of layers upon heating at $200{ }^{\circ} \mathrm{C}$ for $200 \mathrm{~h}$ and subsequent heating $(+)$ at $300{ }^{\circ} \mathrm{C}$ for $50 \mathrm{~h}$. The $\mathrm{Au}$ layer maintains its Au content $85-86$ wt. \% upon heating at $450{ }^{\circ} \mathrm{C}$ for $50 \mathrm{~h}$, the cobalt content of the layer up to $8.6 \mathrm{wt} \%$ and content of oxygen bonded to $\mathrm{Au}$ of $8.6 \mathrm{wt}$. \%. The electrodeposited Au layers $(0.8-1.0 \mu \mathrm{m})$ maintain their structure at heating at $200{ }^{\circ} \mathrm{C}$ and $300{ }^{\circ} \mathrm{C}$ for $200 \mathrm{~h}$. After additional heating at $450{ }^{\circ} \mathrm{C}$ for $30-50 \mathrm{~h}$ gold content in the layer decreases from 98.4 wt. $\%$ to 85.0 wt. \%, cobalt content increases to 7.6 wt. $\%$ and oxygen to 7.2 wt. \%.
\end{abstract}

Keywords: Multilayer systems, gold coating, interdiffusion, barrier layer, elemental composition, structural properties.

\section{INTRODUCTION}

Different thin metal layer systems, such as $\mathrm{Au} / \mathrm{Ni} / \mathrm{Cu}$, $\mathrm{Au} / \mathrm{Fe}-\mathrm{Ni}, \mathrm{Au} / \mathrm{Pd} / \mathrm{Ni}, \mathrm{Au} / \mathrm{Co}, \mathrm{Au} / \mathrm{Pt} / \mathrm{Ti} / \mathrm{InP}, \mathrm{Au} / \mathrm{Ni} / \mathrm{Ti} / \mathrm{InP}$, $\mathrm{Au} / \mathrm{Ru} / \mathrm{Ti} / \mathrm{InP}, \mathrm{Au} / \mathrm{Ru} / \mathrm{Ti}, \mathrm{Cu} / \mathrm{Co}-\mathrm{Ni} / \mathrm{Cu}, \mathrm{Co}-\mathrm{Pt} / \mathrm{Cu}$ are used in microelectronics, electronics and semiconductor products [1-5].

The formation of systems involving the metal layers sputtered on ceramics and of $0.2-3.0 \mu \mathrm{m}$ thick functional metal layers thereon using the electrochemical methods is very actual in microelectronics today [6-8].

Multilayer metal systems must provide the multifunctionality of microelectronics products, their high electrophysical and magnetic properties, solderability, low contact resistance of surfaces and high corrosion resistance. To ensure this, the metal layer systems must possess high thermal stability and mutual adhesion [1, 6, 9-14].

Functional properties of the above multilayer systems deteriorate by mutual diffusion of metal atoms and formation of brittle intermetallics. The latter may give rise to the formation of monolithic films, cause the deterioration of mutual adhesion of the layers and complete reactions of the upper conducting $\mathrm{Sn}$, Au layers with the base metal $\mathrm{Ni}, \mathrm{Cu}$, $\mathrm{Ti}, \mathrm{Sn}[15,16]$. This diffusion can worsen the properties of very thin $(0.5-1.0 \mu \mathrm{m})$ metal layers electrodeposited on a $\mathrm{Cu}$ layer $(1-2 \mu \mathrm{m})$ sputtered on glass-ceramics [15].

Gold is one element whose atoms can form intermetallic compounds with metals $\mathrm{Ni}, \mathrm{Cu}, \mathrm{Al}, \mathrm{Zn}, \mathrm{Pb}, \mathrm{Cd}, \mathrm{Sn}, \mathrm{In}, \mathrm{Ga}$ as

*Address correspondence to this author at the Institute of Inorganic Chemistry, Riga Technical University, 34 Miera Str., Salaspils-1, LV-2169, Latvia; E-mail: ingrida.vitina@inbox.lv a result of diffusion even at room temperature [17]. Similar diffusion properties are characteristic of $\mathrm{Cu}$ and $\mathrm{Ni}$ atoms, also [17-20].

To prevent the mutual diffusion of the interlayer metal atoms, the investigations on formation of interlayers or the so-called barrier layers between the copper substrate and functional $\mathrm{Au}, \mathrm{Sn}$ coatings have become very actual throughout the world in the last 15 years. In the last two decades of the 20th century, such investigations mainly covered the properties of the barrier layers of Ni-P, Ni, Ni-B, $\mathrm{Pd}, \mathrm{Pt}, \mathrm{Co}$ and their alloys [16, 21-24].

Further investigations concerning the properties of barrier layers are related to the use of X-ray amorphous Ni$\mathrm{W}, \mathrm{Co}-\mathrm{W}$, etc. alloys. These investigations are governed by global economic politics, namely, the economy of gold and the tendency to decrease the thickness of gold layers. Along with this, the requirements are increased for providing the functional properties of thin metallic films, such as thermal stability of adhesion, preservation of structure and phase composition under conditions of continuous current and heat. This is why the investigations concerning the electrowinning and properties of nanostructured thin layers of X-ray amorphous Co-W alloys are very actual today [21, 23, 2527].

One of the pioneering studies on the application of $\mathrm{Co}-\mathrm{W}$ alloys for stabilizing the structure of $\mathrm{Au}$ [26] has shown that mutual diffusion of $\mathrm{Fe}$ and $\mathrm{Ni}$ atoms into a 1.0-1.25 $\mu \mathrm{m}$ thick $\mathrm{Au}$ coating in the system of layers $\mathrm{Au} / \mathrm{Co}-\mathrm{W} / \mathrm{Fe}-\mathrm{Ni}$ is prevented by the layer of $\mathrm{Co}-\mathrm{W}$ alloy $1 \mu \mathrm{m}$ thick. The diffusion did not occur upon heating at $500{ }^{\circ} \mathrm{C}$ for $5 \mathrm{~min}$, at $450{ }^{\circ} \mathrm{C}$ for $5-10 \mathrm{~min}$ nor at $300{ }^{\circ} \mathrm{C}$ for $70 \mathrm{~h}$. The content of 
Co in the layer amounted to 50 wt. \% but the content of $\mathrm{W}$ should be at least 40 wt. $\%$.

Formation of X-ray amorphous Co-W alloy depends on the composition of the electrolyte and electrodeposition regime. Co-W alloy layers with a $\mathrm{W}$ content of $40 \mathrm{wt}$. \% [26], 22-38 wt. \% [28] 36 wt. \% [29], 23-40 wt. \% [30] were prepared.

As a result of our investigations, thin layers of X-ray amorphous Co-W alloy containing 46-55 wt. \% of $\mathrm{W}$ have been deposited from the complex salt electrolyte depending on its composition and $\mathrm{pH}$ of the solution. The investigations have shown that the 1.0-1.25 $\mu \mathrm{m}$ thick thin layer of $\mathrm{Co}-\mathrm{W}$ alloy provides the phase and structure stability of gold coatings in the system of layers $\mathrm{Au} / \mathrm{Co}-\mathrm{W} / \mathrm{Cu}$ (foil) upon heating at $400{ }^{\circ} \mathrm{C}$ for $200 \mathrm{~h}$ and at $500^{\circ} \mathrm{C}$ for $15 \mathrm{~h}[31,32]$.

The problem of structure and phase stability of both $0.2-$ $0.5 \mu \mathrm{m}$ thick gold layers obtained by the chemical reduction method and 0.8-1.0 $\mu \mathrm{m}$ thick electrodeposited gold layers on the sputtered copper on ceramics, when exposed to current flow or heat remains very actual. For this reason our further investigations are focused on the possibility of using the electrodeposited amorphous Co-W (W $50 \%$ ) layer as a barrier layer to prevent the interdiffusion of atoms in the system of layers $\mathrm{Au} / \mathrm{Co}-\mathrm{W} / \mathrm{Cu}$ (sputtered)/glass-ceramics.

\section{MATERIALS AND METHODOLOGY}

The changes of structure of $\mathrm{Au}$ and $\mathrm{Co}-\mathrm{W}$ thin layers upon thermal treatment - on duration and temperature of thermal treatment - were studied by means of scanning electron microscopes MREM-100-005, XL-30 ESEN Philips and transmission electron microscope JOEL 100S. The phase stability was evaluated using X-ray diffraction (XRD) with Diffractometer D8 ADVANCE (Bruker AXS GMBH) and DIFFRAC plus Evaluation Package Release 2007-EVA V13 programme. The changes in the elemental composition in the thin layers due to the possible mutual diffusion of atoms were determined using the X-ray microanalysis of electron microscope XL-30 ESEN Philips.

The following electrolyte was used to electrodeposit the thin layer of Co-W amorphous alloy $\left(\mathrm{g} \cdot \mathrm{dm}^{-3}\right): \mathrm{CoSO}_{4} \cdot 7 \mathrm{H}_{2} \mathrm{O}$ 55-63; $\mathrm{Na}_{2} \mathrm{WO}_{4} \cdot 2 \mathrm{H}_{2} \mathrm{O}$ 56-58; disodium salt of ethylenediaminetetraacetic acid $\mathrm{C}_{10} \mathrm{H}_{14} \mathrm{~N}_{2} \mathrm{O}_{8} \mathrm{Na}_{2} \cdot 2 \mathrm{H}_{2} \mathrm{O}$ (EDTA) 26.0-28.0; citric acid 65-70. The electrolyte did not contain ammonium ions nor ammonium salts. The electrolyte $\mathrm{pH}$ was 6.9-7.5. The cathode current density during the electroplating process was $0.8-3.0 \mathrm{~A} / \mathrm{dm}^{2}$; electrolyte temperature was $62-68^{\circ} \mathrm{C}$.

Co-W layers were electrodeposited from the abovementioned electrolyte on vacuum sputtered copper layers (thickness $0.5-1.0 \mu \mathrm{m}$ ). The composition of $\mathrm{Co}-\mathrm{W}$ alloy depending on the electrolyte $\mathrm{pH}$ and cathode current density was controlled using the methods of chemical analysis [31, 32].

Tungsten content in the layer of Co-W alloy was 48-52 wt. \%. The following electrolyte $\left(\mathrm{g} \cdot \mathrm{dm}^{-3}\right): \mathrm{K}\left[\mathrm{Au}(\mathrm{CN})_{2}\right] 12-$ 16; diammonium citrate $15-20$; citric acid $1-2$; benzyl alcohol 2-4\% (by volume), was used to deposit the chemically reduced gold thin layer (0.3-0.5 $\mu \mathrm{m}$ thick).
Electrolyte temperature was $50-70{ }^{\circ} \mathrm{C}$, and electrolyte $\mathrm{pH}$ was 4-9 [31, 32].

The following electrolyte was used to electrodeposit gold layers $0.6-1.5 \mu \mathrm{m}$ thick $\left(\mathrm{g} \cdot \mathrm{dm}^{-3}\right)$ : $\mathrm{K}\left[\mathrm{Au}(\mathrm{CN})_{2}\right]$ 17-6; citric acid 140.0. The electrodeposition was performed under the following conditions: cathode current density from 0.3 to 1.0 $\mathrm{A} / \mathrm{dm}^{2}$, electrolyte temperature $30^{\circ} \mathrm{C}$.

Gold layers were deposited by chemical reduction and electrowinning on electrodeposited $\mathrm{Co}-\mathrm{W}$ layers (thickness 0.8-1.0 $\mu \mathrm{m})$. The temperatures of thermal treatment (200, 300,400 and $500{ }^{\circ} \mathrm{C}$ ) and duration of thermal treatment (up to $200 \mathrm{~h}$ ) were close to the test conditions applied by the authors of Refs [14, 17, 26, 29, 30].

\section{RESULTS AND DISCUSSION}

\subsection{System: Co-W/Cu}

The formation of cobalt-tungsten alloy and coprecipitation of tungsten with cobalt in the electrochemical process depends on electrolyte $\mathrm{pH}$ (Fig. 1). The content of $\mathrm{W}$ in the electrodeposited Co-W alloy layers (thickness 1.0-1.25 $\mu \mathrm{m})$ is $46-53$ wt. $\%$ at $\mathrm{pH}$ varying from 6.9 to 7.3 and cathode current density of $0.8-1.2 \mathrm{~A} / \mathrm{dm}^{2}$. The decrease of the electrolyte $\mathrm{pH}$ to 6.5 causes the decrease of $\mathrm{W}$ content in the alloy to 32 wt. \%. Elevation of electrolyte $\mathrm{pH}$ to 7.3 causes the increase of $\mathrm{W}$ content to $55 \mathrm{wt}$. \%. Such changes in tungsten content in the alloy are due to the different stability of Co and W citrate complexes.

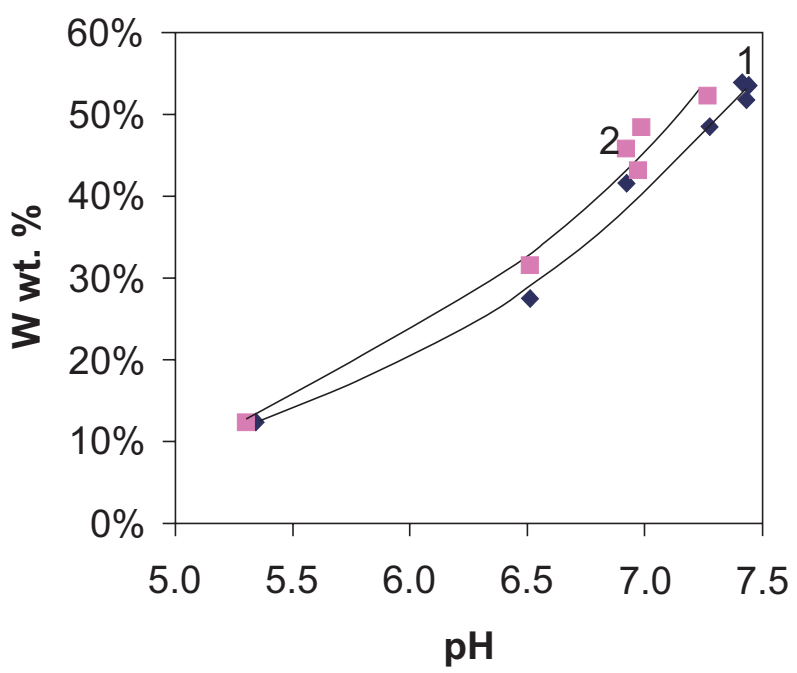

Fig. (1). Content of tungsten in the Co-W alloy depending on electrolyte $\mathrm{pH}$ and cathode current density at electrodeposition: 1 $0.8 \mathrm{~A} / \mathrm{dm}^{2} ; 2-1.2 \mathrm{~A} / \mathrm{dm}^{2}$.

The formation of X-ray amorphous alloy is controlled by the very complicated cathodic process. W cannot be electrochemically deposited on the cathode from the solutions of ions or complex anions. The electrochemical formation of X-ray amorphous alloy thin layers is mainly due to a reduction of $\mathrm{Co}$ and $\mathrm{W}$ on the cathode from highly dispersed combined hydrated $\mathrm{Co}-\mathrm{W}$ oxides formed in the layer adjacent to the cathode under the influence of hydrogen evolution [25]. The ratio of the previously mentioned hydrated Co and W oxides, in turn, is influenced and determined by the stability of the complexes in electrolyte. 


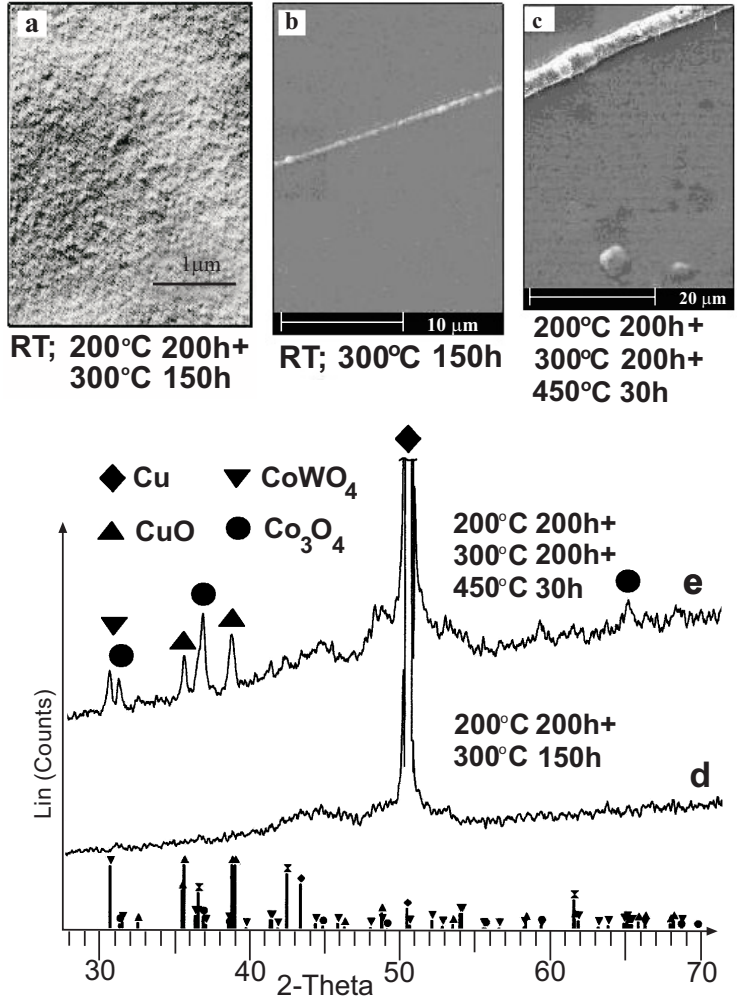

Fig. (2). Changes in structure and phase composition of electrodeposited Co-W alloy thin layer $(\sim 1.0 \mu \mathrm{m})$ depending on the duration and temperature of thermal treatment (RT - room temperature, $\mathrm{h}$ - duration).

The X-ray phase diagrams and micrographs show that the Co-W alloy containing 48.4 wt. \% of Co and 49.5 wt. \% of $\mathrm{W}$ is X-ray amorphous (Fig. 2d). The amorphous state of the Co-W alloy is preserved upon heating at $200{ }^{\circ} \mathrm{C}$ for $200 \mathrm{~h}$ and subsequent heating $(+)$ at $300{ }^{\circ} \mathrm{C}$ for $150 \mathrm{~h}$. Changes in the layer structure occur at additional heating at $200{ }^{\circ} \mathrm{C} 200$ $\mathrm{h}+300{ }^{\circ} \mathrm{C} 150 \mathrm{~h}+450{ }^{\circ} \mathrm{C} 30 \mathrm{~h}$. The formation of crystals of $\mathrm{CoWO}_{4}$ and $\mathrm{Co}_{3} \mathrm{O}_{4}$ can be observed in the structure and phase diagram of the Co-W alloy thin layer (Fig. 2c, e). Changes in elemental composition take place in the layer, too. The content of $\mathrm{Co}$ and $\mathrm{W}$ is decreased gradually from 48.4 and 49.5 wt. $\%$ to 41.4 and 42.9 wt. \%, respectively (Fig. 3a-c); the amount of oxygen bound in the Co-W alloy layer is increased from 2.1 wt. \% to 15.9 wt. \%.

\subsection{System: Au chemically reduced $/ \mathrm{Co}-\mathrm{W} / \mathrm{Cu}$ sputtered / Glass- Ceramics}

The micrographs of structure of the chemically reduced $\mathrm{Au}$ layers show that the structure of the chemically reduced $0.4 \mu \mathrm{m}$ thick $\mathrm{Au}$ layer is retained upon heating the layer system at $200{ }^{\circ} \mathrm{C}$ for $200 \mathrm{~h}$ and subsequent heating at $300^{\circ} \mathrm{C}$ for $50 \mathrm{~h}$ (Fig. 4a, d). Under such a regime of thermal treatment the gold layer retains its $\mathrm{Au}$ content of $86 \mathrm{wt}$. \% (Fig. 5b). After additional heating at $450{ }^{\circ} \mathrm{C}$ for $50-80 \mathrm{~h}$, the spontaneous growth of Au crystals begins (Fig. $\mathbf{4 b}$, e). The latter is favoured by the incomplete crystallization of gold in the course of the chemical reduction process; crystallization is continued on heating of the layer system.
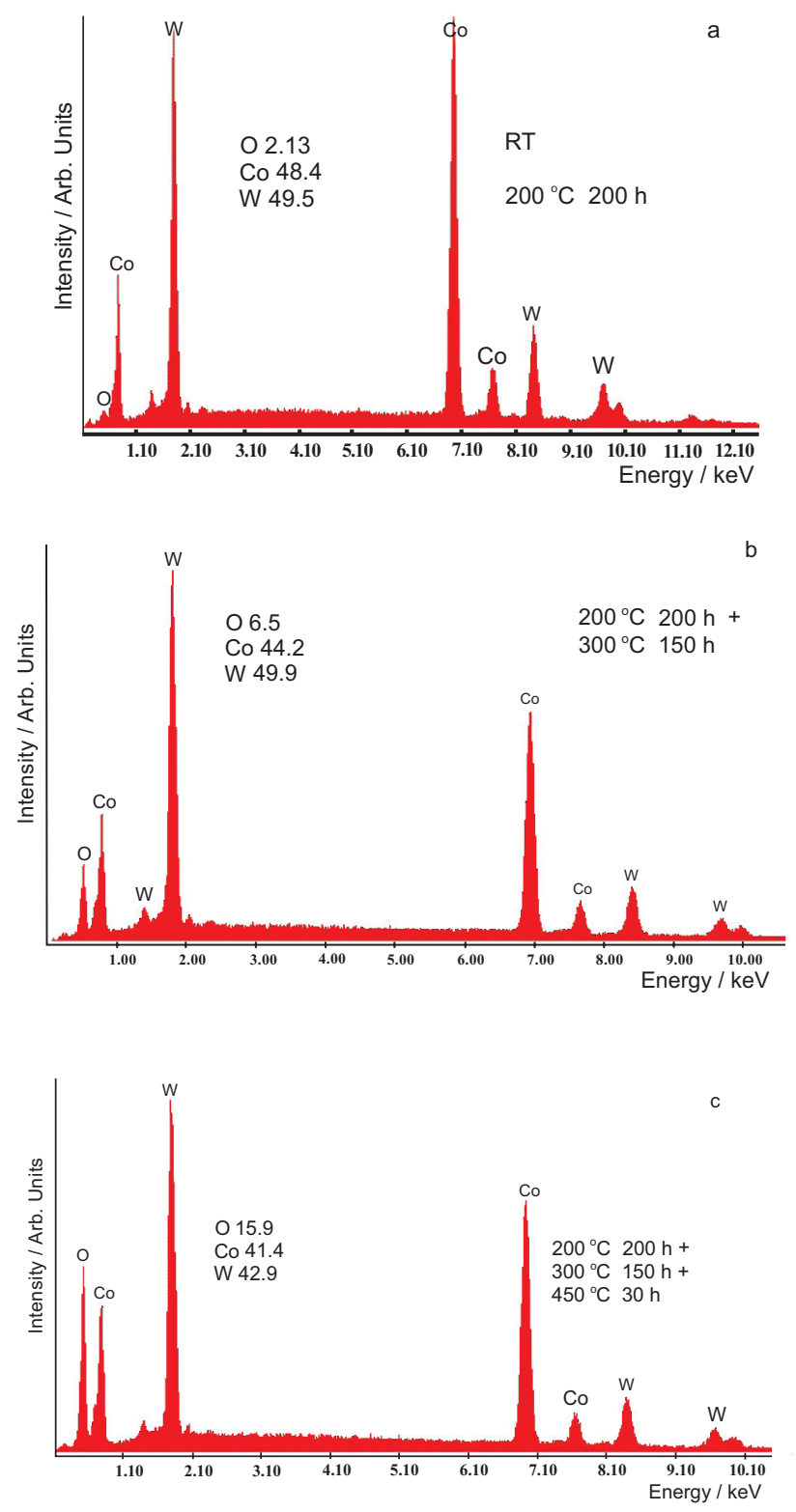

Fig. (3). Changes in elemental composition (wt. \%) of the electrodeposited Co-W thin layer $(\sim 1.0 \mu \mathrm{m}$ thick $)$ depending on the duration and temperature of thermal treatment.
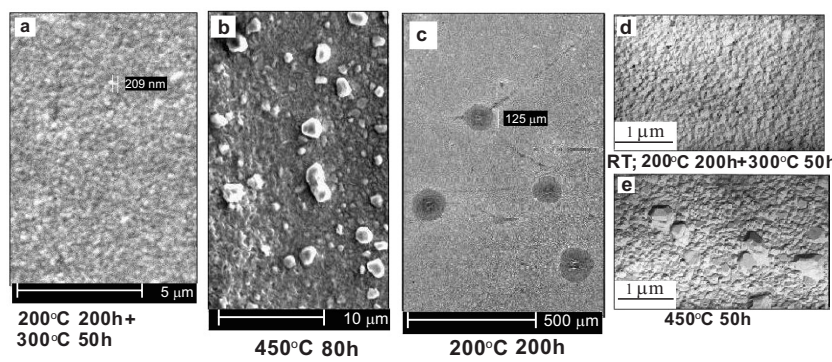

Fig. (4). Changes in structure of the chemically reduced $\mathrm{Au}$ thin layers $(0.4 \mu \mathrm{m})$ depending on the duration and temperature of thermal treatment in the system of layers: $\mathrm{Au}$ chemically reduced $/ \mathrm{Co}-$ $\mathrm{W} / \mathrm{Cu}$ sputtered / glass-ceramics: a, b, c - scanning electron micrographs; $\mathbf{d}, \mathbf{e}-$ transmission electron micrographs of structure of gold layers. 
The changes in the elemental composition of the thin layer subjected to the two regimes of thermal treatment heating at $450{ }^{\circ} \mathrm{C}$ for $50 \mathrm{~h}$ - show that under conditions of prolonged heating the cobalt content in the layer increases from $5.3 \mathrm{wt}$. $\%$ to $8.6 \mathrm{wt}$. $\%$ and oxygen content - to $6.0 \mathrm{wt}$. $\%$ (Fig. 5b).

If the sputtered $\mathrm{Cu}$ film has pores or other defects, they are repeated in the electrodeposited $\mathrm{Co}-\mathrm{W}$ layer and chemically reduced gold layer (Fig. 4c). In such spots diffusion of copper atoms starts, and finally the amount of copper in the gold layer may reach 50 wt. \% (Fig. 5c).

According to the XRD pattern, Au retains its phase and the diffusion of $\mathrm{Cu}$ atoms through the $\mathrm{Co}-\mathrm{W}$ barrier layer is not observed. Also the broadening of reflections corresponding to gold, the decrease of their intensity and the formation of intermetallics $\mathrm{Au} \mathrm{Cu}$ are not observed (Fig. 6ad).

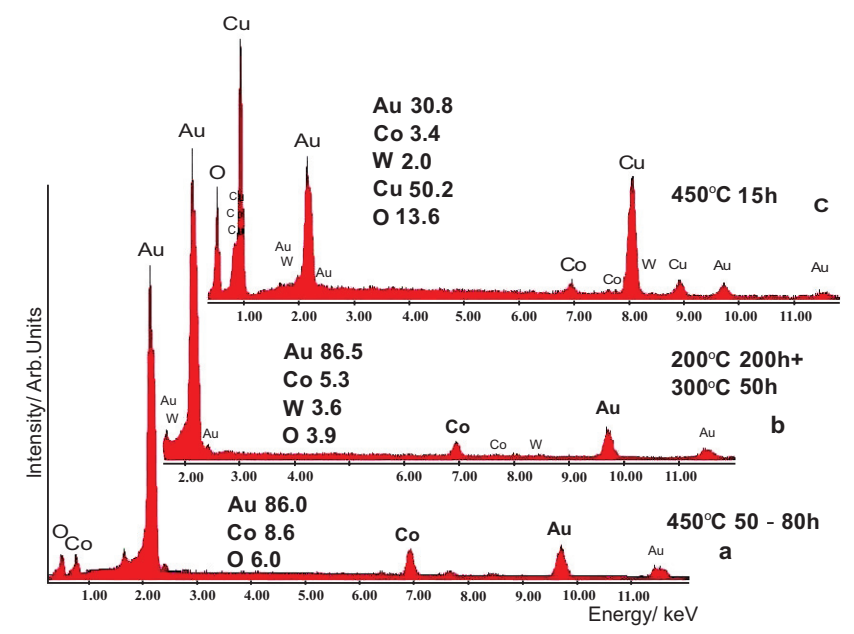

Fig. (5). Changes in elemental composition of the chemically reduced $\mathrm{Au}$ thin layers $(0.4 \mu \mathrm{m})$ depending on the duration and temperature of thermal treatment in the system of layers: $\mathrm{Au}$ chemically reduced $/ \mathrm{Co}-\mathrm{W} / \mathrm{Cu}_{\text {sputtered }} /$ glass-ceramics.

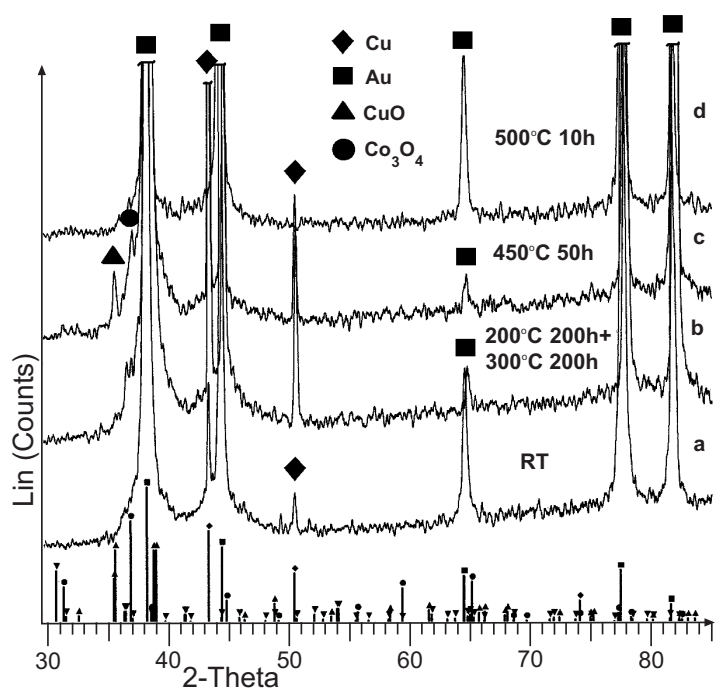

Fig. (6). Stability of phase composition of chemically reduced Au thin layers depending on the duration of thermal treatment and spontaneous growth of $\mathrm{Au}$ crystals in the system of layers: $\mathrm{Au}$ chemically reduced $/ \mathrm{Co}-\mathrm{W} / \mathrm{Cu}_{\text {sputtered }} /$ glass-ceramics.
3.3. System: Au electrodeposited $/ \mathrm{Co}-\mathrm{W} / \mathrm{Cu}$ sputtered / GlassCeramics

The thickness of electrodeposited Au layers is $0.8-1.0$ $\mu \mathrm{m}$. The thermal treatment at $200{ }^{\circ} \mathrm{C}$ and $300{ }^{\circ} \mathrm{C}$ for $200 \mathrm{~h}$ does not cause changes in the structure of the gold layer system in comparison with the structure obtained without heating (Fig. 7a, b). After additional heating at $450{ }^{\circ} \mathrm{C}$ for 30-50 h, the spontaneous growth of gold crystals begins (Fig. $\mathbf{7 c}, \mathbf{d})$. The spontaneous growth of crystals on the surface of the Au thin layer in this case is determined by the physical properties of gold, e.g. by the tendency to form such crystals that is also characteristic of metals $\mathrm{Zn}, \mathrm{Cd}, \mathrm{Sn}$.
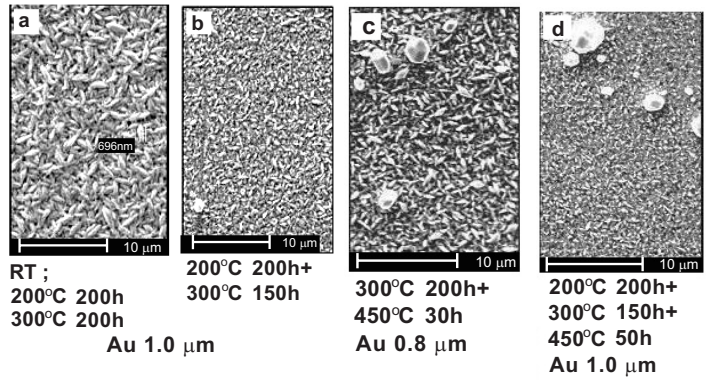

Fig. (7). Changes in structure of the electrodeposited Au layers depending on the duration and temperature of thermal treatment in the system: $\mathrm{Au}$ electrodeposited $/ \mathrm{Co}-\mathrm{W} / \mathrm{Cu}_{\text {sputtered }} /$ glass-ceramics.

The elemental composition of gold coating changes upon heating of the layer system. Gold content in the layer decreases from 98.4 wt. $\% 200{ }^{\circ} \mathrm{C} 200 \mathrm{~h}$ and 93.5 wt. $\% 300$ ${ }^{\circ} \mathrm{C} 200 \mathrm{~h}$ (Fig. 8a) to 89.0 wt. \% and 85.0 wt. \% (Fig. 8b, c). Cobalt content in the layer increases from 2.7 wt. \% to 5.3 wt. $\%$ and 7.6 wt. $\%$ along with increase of duration and temperature of thermal treatment. Such a phenomenon can be caused by diffusion of Co atoms into the Au layer. The elemental analysis data show that at sites of spontaneous growth of $\mathrm{Au}$ crystals, the gold content in the layer is decreased to 73.0 wt. \%; diffusion of $\mathrm{Cu}$ atoms starts parallel with the diffusion of Co atoms (Fig. 8d). The gold layer incorporates oxygen from $3.5 \mathrm{wt}$ \% to $10.3 \mathrm{wt}$. \% at all the temperatures of thermal treatment tested (Fig. 8a-c).

XRD patterns show that the formation of intermetallic $\mathrm{Au}-\mathrm{Cu}$ layers is not observed in the system of layers $\mathrm{Au}$ electrodeposited $/ \mathrm{Co}-\mathrm{W} / \mathrm{Cu}_{\text {sputtered }} /$ glass-ceramics with the barrier layer of Co-W (Fig. 9).

\section{CONCLUSIONS}

1. The different stabilities of Co and $\mathrm{W}$ citrate and ethylenediaminetetraacetate (EDTA) complexes were determined as functions of the solution $\mathrm{pH}$ in the absence of ammonium ions. The different stabilities of $\mathrm{Co}$ and $\mathrm{W}$ complexes determine whether it is possible to obtain Co-W alloy having the $\mathrm{W}$ content 30-55 wt. \%.

2. Changes in the phase and elemental compositions of the thin layer of the electrodeposited amorphous alloy W 46.0-53.0 wt. \% were determined for different heating times and temperatures. The $\mathrm{Co}-\mathrm{W}$ layer maintains its amorphous state after heating at $200{ }^{\circ} \mathrm{C}$ for $200 \mathrm{~h}$ and subsequent heating at $300^{\circ} \mathrm{C}$ for $150 \mathrm{~h}$. Crystallization of the $\mathrm{Co}-\mathrm{W}$ layer with formation of $\mathrm{CoWO}_{4}$ and $\mathrm{Co}_{3} \mathrm{O}_{4}$ crystals starts upon additional 


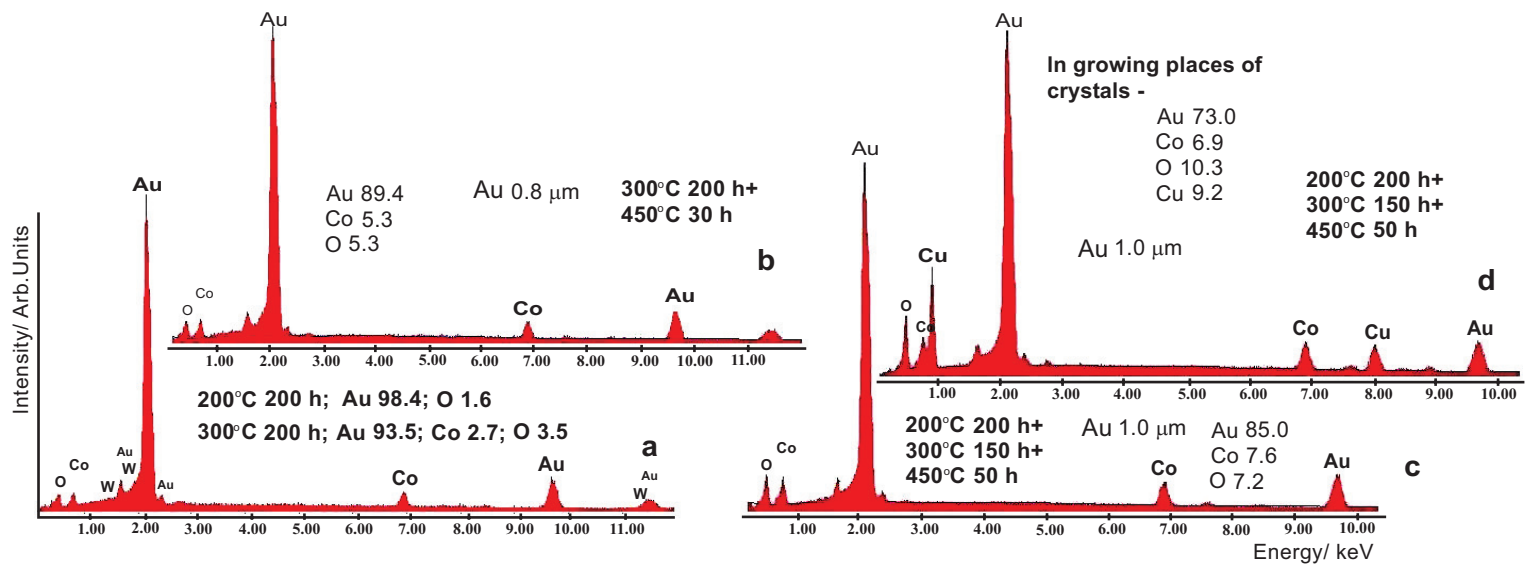

Fig. (8). Changes in elemental composition of the electrodeposited Au layer depending on the duration and temperature of thermal treatment.

heating at $450{ }^{\circ} \mathrm{C}$ for $30 \mathrm{~h}$. The Co and $\mathrm{W}$ contents in the layer gradually decrease from 48.4 wt. $\%$ of Co and 49.5 wt. $\%$ of $\mathrm{W}$ to 41.1 and 42.9 wt. \% respectively. The content of the oxygen bonded in the Co-W layer increases from 2.1 to $16.0 \mathrm{wt}$ \%.

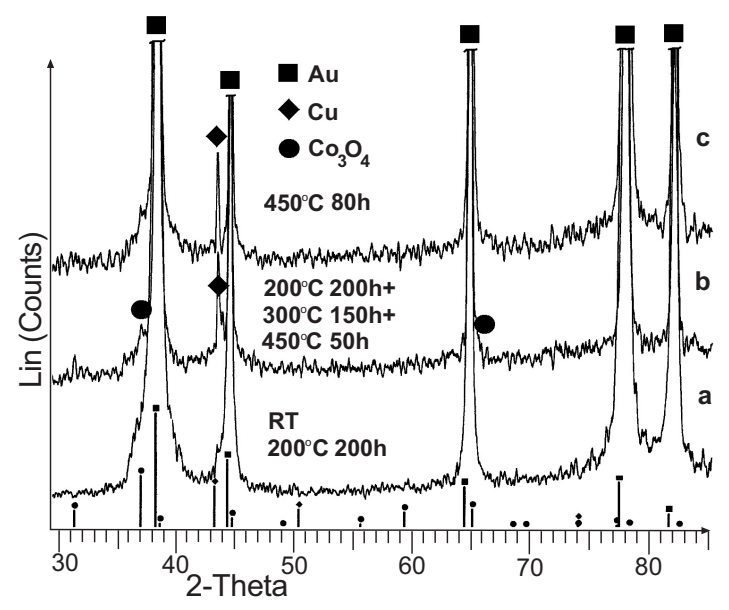

Fig. (9). Stability of phase composition of the electrodeposited $\mathrm{Au}$ layers after thermal treatment.

3. Chemically reduced $0.4 \mu \mathrm{m}$ thick layers maintain their structure and phase in the system of layers $\mathrm{Au}_{\text {chemically reduced }} / \mathrm{Co}-\mathrm{W} / \mathrm{Cu}_{\text {sputtered }} /$ glass-ceramics upon heating at $200{ }^{\circ} \mathrm{C}$ for $200 \mathrm{~h}$ and additional heating at $300{ }^{\circ} \mathrm{C}$ for $50 \mathrm{~h}$. The layer maintains its $\mathrm{Au}$ content of 86 wt. \%. The Co content in the Au layer is 5.3 wt. \% and the content of the oxygen bonded to Au 3.9 wt. $\%$. Upon heating at $450{ }^{\circ} \mathrm{C}$ for $50-80 \mathrm{~h}$ the Co content in the Au layer increases to $8.6 \mathrm{wt}$. \% and oxygen to 6.0 wt. $\%$.

4. Electrodeposited $\mathrm{Au}$ layers (thickness $0.8-1.0 \mu \mathrm{m}$ ) maintain their structure upon heating at $200^{\circ} \mathrm{C}$ and $300^{\circ} \mathrm{C}$ for $200 \mathrm{~h}$. Upon additional heating at $450^{\circ} \mathrm{C}$ for $50 \mathrm{~h}$, spontaneous growth of gold crystals starts. Under these heating conditions, the $\mathrm{Au}$ layers maintain their phase.

5. A thin layer (thickness approx. $1 \mu \mathrm{m}$ ) of amorphous $\mathrm{Co}-\mathrm{W}$ alloy prevents interdiffusion of $\mathrm{Au}$ and $\mathrm{Cu}$ atoms and formation of intermetallics $\mathrm{AuCu}$ in the systems of layers $\mathrm{Au}$ chemically reduced; electrodeposited $/ \mathrm{Co}-$ $\mathrm{W} / \mathrm{Cu}$ sputtered/glass-ceramics upon heating at $200{ }^{\circ} \mathrm{C}$ $200 \mathrm{~h}+$ (subsequent heating) $300{ }^{\circ} \mathrm{C} 200 \mathrm{~h} ; 450{ }^{\circ} \mathrm{C}$ for $50-80 \mathrm{~h} ; 500{ }^{\circ} \mathrm{C}$ for $10 \mathrm{~h}$.

\section{REFERENCES}

[1] Dambrowsky N, Schulz J. Gold plating in microsystem techology. Challenges by new applications. Wissenschaftliche Berichte Forschungszentrum Karlsruhe 2007 (FZKA 7308).

[2] Kabayashi K. Surface treating of iron alloy electronic components. Jpn. Kokai Tokkyo Koho JP 2006 83, 409 Cl. C25 D5/14, March 30, 2006.

[3] Qian Hao, Qiu Hong, Wu Ping, et al. Effect of annealing on the characteristics of $\mathrm{Au}$ layers grown on the high-temperature deposited $\mathrm{Ni}_{80} \mathrm{Fe}_{20}$ layers. Vacuum 2006; 80: 899-903.

[4] Bär G, Ruhlicke D. Galvanischer Schichtverbundwerkstoff $\mathrm{Ni} / \mathrm{PdNi} / \mathrm{Au}$ für elektrotechnische Anwendungen. Metall 1991; 45: 668-73.

[5] Ruythooren W, Attenborough K, Beerten S, et al. Electrodeposition for the synthesis of microsystems. J Micromech Microeng 2000; 10: $101-7$.

[6] Lahmar A, Nguyen TP, Sakami D, Orain S, Scudeller S, Danes F. Experimental investigation on the thermal contact resistance between gold coating and ceramic substrates. Thin Solid Films 2001; 389: 167-72.

[7] Munoz-Martin A, Vila M, Prieto C, Ocal C, Martinez JL. Microstructural characterization of iron thin films prepared by sputtering at very low temperature. Vacuum 2002; 67: 583-8.

[8] Jakubec A, Rehacek V, Novotny I, et al. Thin films for electrochemical sensoric interfaces. Proceedings of the 4th International Conference on Advanced Semiconductor Devices and Microsystems, Smolenice Castle, Slovakia, October 2002; Inst Electrical and Electronics Engineers, New York 2002; pp. 321-4.

[9] Mamoru I, Noboru A, Nobuyoshi H, Katsuhisa S, Sigeo F. Corrosion of multilayers used for magnetoresistive head in aqueous solution environment. J Jpn Inst Metals 1997; 61: 64-70.

[10] Xin WR, Yitshak Z, Man W. The effects of process-induced stress on the microstructures and the phase transformation characteristics of sputtered titanium-nickel thin-film shape-memory alloys. J Micromech Microeng 2001; 11: 686-91.

[11] Ren F, Abernathy CR, Pearton SJ, Wisk PW. Thermal stability of Ti/Pt/Au nonalloyed ohmic contacts on InN. Appl Phys Lett 1994; 64: 1508-10.

[12] Wang RN, Feng JY. Comparison of the thermal stabilities of NiSi films in Ni/Si, Ni/Pd/Si and Ni/Pt/Si systems. Condensed Matter J Phys 2003; 15: 1935-42.

[13] Kinyanjui RK, Zribi A, Cotts EJ. Effects of reflow conditions on the formation of $\mathrm{Au}-\mathrm{Ni}-\mathrm{Sn}$ compounds at the interface of $\mathrm{Au}-\mathrm{Pb}-\mathrm{Sn}$ and $\mathrm{Au}-\mathrm{Sn}$ solder joints with $\mathrm{Ni}$ substrate. Proceedings of the Electronic Components and Tehnology Conference; Binghamton University, State University of New York 2002; vol. 52: pp. 161-7. 
[14] Snugovsky L, Ruggiero MA, Perovic DD, Rutter JW. Experiments on interaction of liquid tin with solid copper. Mater Sci Technol 2003; 19: 866-74.

[15] Vìtina I, Pelēce I, Rubene V, et al. Formation of intermediate intermetallic layers on interaction of electrodeposited Sn, Ni-Fe, $\mathrm{Ni}-\mathrm{B}$ coatings with different metallic substrata. J Adhesion Sci Technol 1997; 11: 835-60.

[16] Vītina I, Rubene V, Lubāne M, Belmane V, Krūmiṇa A, Knipele A. Structure and phase stability of the chemically deposited $\mathrm{Au}$ layers on electrodeposited Ni and Ni-B layers. Surf Coat Technol 1999; 120/121: 430-7.

[17] Marinkovic Z, Simic V. Kinetics and mechanism of reaction at room temperature in thin Au/metal couples. Thin Solid Films 1988; 156: $105-15$

[18] Chen HT, Wang CQ, Li MY, Tian DW. Effect of Cu diffusion through $\mathrm{Ni}$ on the interfacial reactions of $\mathrm{Sn} 3.5 \mathrm{Ag} 0.75 \mathrm{Cu}$ and $\mathrm{SnPb}$ solders with $\mathrm{Au} / \mathrm{Ni} / \mathrm{Cu}$ substrate during aging. Mater Lett 2006; 60: 13-4.

[19] Herzig Ch. Schneller Fremdatomtransport in einigen Basismetallen der III und IV Grupe des periodischen Systems. Metallkunde 1981; 72: 601-7.

[20] Yongxin W, Xiaozhong W, Zhixiong Y, Zulong X, Zhiyong L. Comparison of diffusion properties of copper in nickel, cobalt and palladium deposits. Diandu Yu Tushi 2000; 19: 4-7.

[21] Lang Ch, Schmitz G. Microstructure-controlled interdiffusion of $\mathrm{Cu} / \mathrm{Co} / \mathrm{Au}$ thin films investigated by three-dimensional atom probe. Mater Sci Eng 2003; A353: 119-25.

[22] Asahara H, Fukamachi K. Gold or gold plating on electronic parts having high corrosion and heat resistance. Jpn Kokai Tokkyo Koho JP 2001 89, 895 Cl. C25 D7/00, April 3, 2001.

[23] Asahara H, Fukamachi K. Gold base electroplated material for electronics component and its production. Jpn Kokai Tokkyo Koho JP 2001 03, 192 Cl. C25 D3/56, June 9, 2001.
[24] Yongxin W, Xiaozhong W, Zhixiong Y, Zulong X, Zhiyong L. Co$\mathrm{W}$ alloy electrodeposited as barrier for $\mathrm{Cu}$ diffusion. Diandu $\mathrm{Yu}$ Tushi 2000; 19, 6: 1-7.

[25] Iyoko Y, Haruyama S. Induced codeposition of amorphous cobaltbase alloys. J Jpn Inst Metals 1989; 53: 100-5.

[26] Nobel Fr, Ostrow BD. Swiss pat. 610354, Schweizerisches PatentMuster und Marken-Blatt. Teil 2. Erfindungspatente 1979; Nr.7: pp. 197.

[27] Hibbard G, Aust KT, Palumbo G, Erb U. Thermal stability of electrodeposited nanocrystalline cobalt. Scr Mater 2001; 44: 513-8.

[28] Donten M. Bulk and surface composition, amorphous structure and thermocrystallization of electrodeposited alloys of tungsten with iron, nickel and cobalt. J Solid State Electrochem 1999; 3: 87-96.

[29] Chow KM, Ng WY, Yeung LK. Interdiffusion of $\mathrm{Cu}$ substrate/ electrodeposits for $\mathrm{Cu} / \mathrm{Co}, \mathrm{Cu} / \mathrm{Co}-\mathrm{W}, \mathrm{Cu} / \mathrm{Co} / \mathrm{Ni}$ and $\mathrm{Cu} / \mathrm{Co}-\mathrm{W} / \mathrm{Ni}$ systems. Surf Coat Technol 1998; 99: 161.

[30] Maruthi BN, Ramesh L, Mayanna SM, Landot D. Electrodeposition and characterization of Co-W alloys. Plat Surf Finish 1999; 86: 85 .

[31] Vītina I, Rubene V, Knipele A, Krūmina A, Lubāne M, Belmane V. Characterization of Structure and Phase Composition for Gold and Cobalt-Tungsten Layers in the Systems Au(electrodeposited $/ \mathrm{Co}-\mathrm{W} / \mathrm{Cu}$. The International Conference on Metallurgical Coatings and Thin Films; April-May 2001; San Diego, California 2001; p. 51.

[32] Vītiņa I, Knipele A, Ašaks J, Pultraks P, Rubene V, Krūmiņa A, Lubāne M. Electrodeposition and properties of thin layers of Co-W alloy amorphous to X-ray diffraction, and composite (Co-W)hydroxylapatite to modify surfaces of materials. Proceedings of the 10th International Baltic Conference - Materials Engineering and Balttrib 2001; September 2001; Jurmala, Latvia 2001; p. 130.

Received: July 13, 2009

Revised: December 10, 2009

Accepted: December 22, 2009

(C) Vītiņa et al.; Licensee Bentham Open.

This is an open access article licensed under the terms of the Creative Commons Attribution Non-Commercial License (http://creativecommons.org/licenses/by-nc/ $3.0 /$ ) which permits unrestricted, non-commercial use, distribution and reproduction in any medium, provided the work is properly cited. 